\title{
Islamic Education and Human Construction In The Quran
}

\author{
Aziz Abdullah a,1,*, Siswanto Masruri ${ }^{\mathrm{b}, 2}$, Khoiruddin Bashori ${ }^{\mathrm{c}, 3}$ \\ ${ }^{\text {a }}$ Universitas Muhammadiyah Yogyakarta, Indonesia

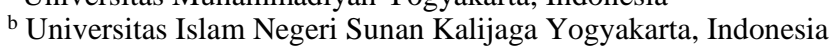 \\ ${ }^{c}$ Universitas Ahmad Dahlan, Indonesia \\ ${ }^{1}$ azisabdullah2018@gmail.com*; ${ }^{2}$ sismasruri@gmail.com; ${ }^{3}$ bkhoiruddin@yahoo.com \\ * corresponding author
}

\section{ARTICLE INFO}

Article history

Received 2019-05-31

Revised 2019-05-29

Accepted 2019-06-01

Keywords

Human Potential

Human Construction

Function Development

Human Earth

Islamic Education

\begin{abstract}
This research patterned literature by examining and tracing various literature, relating to human construction in the Koran. Research findings that humans from the creation process have various potentials and functions of life in this world. So that humans have a position of choice, the best human being and the main human being. The human position of choice is in words, namely: mukhlason (clean / choice), al-Mushthofaina (chosen people), and al-Khiyarah (choice). The best human position is found in the word al-husna (best) and husnu (the best). The process of relevance and development with the world of education, that education as a strategic means aims to develop or cultivate the basic physical and spiritual abilities of humans as caliphs.
\end{abstract}

This is an open access article under the CC-BY-SA license.

\section{Introduction}

Humans as the perfect creatures of God (Q.S. at-Tĩn: 5), have a perfect body structure, with different reasoning and can be developed and grounded in every human being. Human potential can develop into a variety of multiple intelligences. Through the introduction of the types of intelligence possessed by children, adolescents, and even adults, educators, parents or guardians can have a major impact on life in each of their caregivers or students.

Someone who has multiple intelligence always guided his behaviour [1] through a learning process[2] to produce success[3]. Therefore to achieve human intelligence must learn, because by learning humans will be better, smarter, wiser, fairer, obedient to God and a million other goodness with various intelligence [4]. Therefore humans are required to find their potential and actualise in reality for the benefit of society[5].

Human potentials are depicted in multiple intelligences consisting of nine intelligences by Gardner[6]; nine intelligences consist of verbal linguistics related to both oral and written words. Mathematically is intelligence in numbers or numbers, causal and problem-solving relationships. Visual-spatial namely the ability to capture colour, direction and space accurately and transform it into other forms such as architecture, painting, sculpture. Kinesthetic is related to the ability to use gestures to express ideas and messages and the skills to use hands to create and change things. Rhythm-music related to the ability to capture sounds, distinguish, compose and express themselves through sounds/sounds that are pitched and rhythmic. Interpersonal is the ability to understand and work with other people. Intrapersonal is intelligence that is related to the ability to understand oneself and responsibility for one's own life. Naturalists are the ability to recognise, distinguish, classify and make categories of nature and the environment. Eksistensional namely the ability to place oneself 
within the farthest cosmos, with the meaning of life, the meaning of death, the fate of the physical or psychological world and the meaning of deep experiences such as love or art.

\section{Method}

Qualitative research is shown to describe and analyze phenomena, as well as the investigation process to understand and interpret the meaning of a text [7]. This type of research is library research, by reviewing and tracing various literature. The researcher calls the concept research, as stated by the Akif Khilmiyah, what is meant is a process to describe logically and systematically a concept, so that it can be understood with the same view [8].

The approach used is psycho-anthropology, namely the study of humans [9] from the side of the human psyche related to human construction in the Qur'an. The psycho-anthropological approach is used to obtain the scientific side of the human psyche and its functions, to enrich and support the approach of various interpretations of the Qur'an.

The researcher used the Tafsir Maudhu'i method, meaning that the effort to gather verses of the Qur'an related to the topic had been determined, then the researcher discussed and analyzed the content of the verses into complete and complete unity. The steps are carried out by collecting verses in the Qur'an related to intelligence and paying attention to the text of the hadiths of the Prophet relating to intelligence. Through the method above, the researcher will conclude describing the answers of the Qur'an. The technique of collecting resources with the documentation method is a way to obtain information from data in the form of writing, notes, and other objects[10]. Suharsimi Arikunto emphasized the method of documentation is how to find data in the form of notes, achievements, agendas and so on [11].

\section{Results and Discussion}

\subsection{Human Construction}

Historically the creation of the first man, humans has always been juxtaposed with their partners. Since the beginning, humans need other people and always display social behaviour in aspects of their humanity. The next term human means Bashar (al-Mukminnn: 33) which shows the biological aspects and physical properties. Other terms are insane (ar-Rahman: 3-4) and al-Ins (al-Anam: 128 and 130) which show human intelligence, namely the best human being endowed with reason, to be able to explore science [12].

Humans are seen from the aspect of philosophy, humans as a problem because the only creature that can ask questions about themselves, their existence and world. Humans are created to give loyalty, serve and worship only to their creators [13]. Deep questions through the stages of being aware of a problem, doubting and testing rationally, examining and considering the problem, drawing hypotheses and conclusions rationally that can be accounted for [14].

Humans as social beings (al-Basyar) are not much different from other biotic creatures. Although the organ structure is different, the structure of human organs is more perfect when compared to other creatures. Humans as psychic beings (al-Insân) have potential such as fitrah, qalb, reason and other potentials. Then humans as social beings have social duties and responsibilities towards the universe.Also, humans are also servants of Allah and khalifatullah to create prosperity, happiness in the world and the hereafter [14].

Humans in terms of physical, completeness and balance of limbs, joints, various senses, muscles, nervous system, provide flexibility to carry out life activities. In terms of lust, it is an instrument that gives an impulse to behave to meet human needs, to be able to survive and produce to continue the generation of mankind. The word nafs in the Qur'an is around 300 verses which have several meanings. The Nafs is interpreted as a human species (totality of his self) QS. Al-Anâm verse 98 . The nafs is interpreted as a heart contained in QS. Al-Isrâ verse 25. Nafs is interpreted as soul (spirit) or animate, for example in Surah Ali Imran verse 145. Nafs is interpreted as the Substance of Allah the Most Holy in QS. Al-Anâm verse 12. Nafs mean as inclination (lust) in Surah Yusuf verse 53. Finally the miracles in the heart are meaningful flipping because they often turn back, one day happy and at other times difficult, one day agree when others refuse. The word qalb is found in the Qur'an not less than 168 places. 
The uniqueness of man in the heart, the first aspect of the heart that is functioned will be very sensitive to truth and goodness, the two that are not functioned will harden, be insensitive and closed from goodness and truth. For example in QS. Al-Baqarah verses 7 and 74; Al-An'am verse 43; AlA'řaf verses 100-101; At-Taubah verse 87; Jonah verse 74; An-Nahl verse 108, Ar-Rûm verse 59; AlJâsiyah verse 23; Muhammad verse 16; Al-Munâfiqûn verse 3. This is by nature early human events created by God. Humans are creatures that are bound by the agreement, as beings who are aware of their position as God's creation and at the same time as caliphs who carry out the mandate on earth, which is given the potential of the mind to manage nature, oneself to the perfection of life [15].

Man as a mysterious creature of God about his essence and existence can develop himself through three stages: First, the aesthetic stage is the stage of the orientation of human life to obtain mortal pleasure. The two ethical stages of changing the aesthetic lifestyle become ethical, there are aspects of repentance and binding themselves to Him: the third stage, the religious stage which merges into the reality of God. Life in God is living in a transcendent, without rationalisation and without bonding to something worldly [16].

The essence of man in the task of the caliph on earth is the journey of life towards perfection, using carrying out God's commands. The appointed Caliph must fulfil the requirements of men, independent, mature, intelligent, Muslim, fair, mujtahid, alert, healthy, experienced and income. The human reason as an officer on earth, because it has intelligence, various knowledge and can manage this earth so that it can provide benefits and meet the needs of human life [17]. Wisdom was created as a caliph on earth, that is to carry out their duties as caliphs and worship Allah. This means that the mandate that is charged to humans and worship is carried out according to Allah's rules, such as there are commands and prohibitions and wisdom behind something that is commanded by Allah and also accountability in carrying out duties on earth [18]. The task of the caliph is a mandate that is related to mu'amalah, which is an aspect that concerns the relationship between humans and humans in society and all human activities are valued as worship.

The main task of the caliph on earth is to manage the earth responsibly by using his mind, for human happiness in the world and in the end. Therefore, humans with maturity are able to assume responsibility as caliphs. The fundamental problem is by understanding the philosophical values of the creation of man as caliph fi al-ard (leader on earth), as illustrated in surah al-Baqarah verses 3032 , through the meaning revealed in it. In interpreting this Mustafa al-Maragi, said that the caliph was God's representative on the face of the earth [19]. According to al-Shabuni, the caliph was Adam and the following people who partially replaced another in different periods and generations [20].

Functionally the meaning of caliph is a substitute or executor. Adam as the first father as caliph on earth, as David also as the caliph of the next generation. Then the journey of the Caliph must be able to fill the function properly, based on truth and justice and not with the passions based on his own will so that humans get the security of the soul. The qualities possessed by a caliph as explained in the Qurân sura al-Anbiŷa verses 72-73. Like the nature of doing virtue, establishing prayer, performing zakat, and only to Allah they always worship.

The duties of leaders and role models of society are very noble in the sight of Allah, namely calling on people to the religion of God, working on obedience and avoiding immorality. The tasks of leadership are always replaced with better offspring, such as the phenomenon of the substitution of Abraham by his son Isaac and grandson Ya'qub, to guide humans with the command of Allah. Therefore, before repairing other people, the leader of the people must really get God's guidance and improve themselves first. The qualities possessed are special and submissive, not arrogant and giving worship to Allah. Muhammad Quraish Shihab requires that a leader must have a noble personality and noble character according to the guidance of Allah SWT [21].

The mirror of leadership perfection is always based on traits namely Siddiq, Trust, Tabligh and Fathonah. These qualities were given to the Prophet Muhammad in order to carry out his apostolic functions [22].

\subsection{Smart Human Position}

The human position means the secret treasury of God, meaning as the key holder of His wisdom, according to the word of Allah which means: O calm soul, return to your Lord with a heart that is pleased and pleased with Him. Then enter into my class of servants, and enter into my heaven.

According to Ibn Kathir's interpretation that Ibn Abbas may. when explaining this verse above, he said when this verse came down, there was Abubakar sitting and said: O Messenger of Allah, how good is the person who gets the greeting. So the Prophet said: Remember that word will be said to 
you. Strengthened with a prayer that Abu Umamah RA. said: The Messenger of Allah said to someone, read:

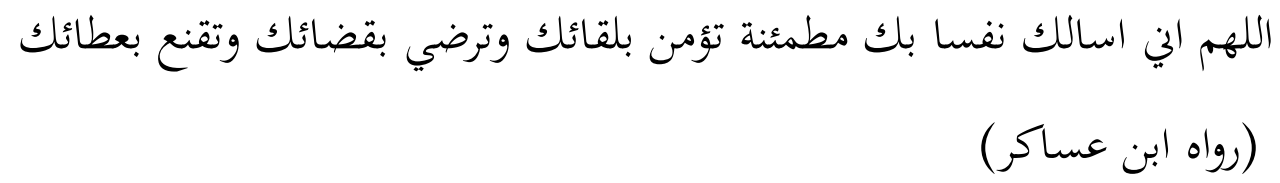

Meaning: O Allah, I ask you a soul that is always at peace with You, believing that You will face You and be willing with the law of Your verdict and accept Your gifts.

Hamka explains nafsul muthmainah is a soul that reaches calm and peace. A soul that has been galvanized by experience, suffering, and a winding road, so it never complains. Calm and peace can be obtained through two wings, namely gratitude when getting wealth and patience when sustenance is just off food and has a high and noble degree, namely with the prophets, apostles, shidiqin and martyrs.

The human position of choice is humans who realize that they have come to the world, with His guidance, then they are happy because they know their position on this earth. Another position is that humans are very dear and love God, even though their servants are guilty and face God with regret with repentance and promise that they will not do it again, the arrival of servants is greeted with affection and finally the chosen man is a generous human, meaning to live with His sifaf, like He is omniscient, Hearing, Seeing, Forgiving rather than punishing [23].

More clearly the position of intelligent human beings based on the Qur'an, researchers find the meaning of the chosen human being, the best human being and the main human being. The human position of choice is in words, namely: mukhlason (clean / choice), al-Mushthofaina (chosen people), and al-Khiyarah (choice). The best human position is found in the word al-husna (best) and husnu (the best). Intelligent humans are in the main human position, contained in the words yatafadlola (above / higher), fadlun fadlun / tafdilan (virtue/superiority), khair (better main), hall or fa hall (preferably) and al-mutslaa (main /well).

\subsection{Relevance with Islamic Education}

The process of relevance and development with the world of education, that education as a strategic means aims to develop or cultivate the basic physical and spiritual abilities of humans as caliphs to reach the optimum point, so that it becomes a useful tool in the pursuit of humanity in carrying out the basic tasks of life in the world [24], But the process of human development through education will not automatically form character and one's talents to be good, considering that God has outlined in human beings there are two two-way tendencies, namely toward wicked deeds and toward piety. this is in accordance with the word of Allah swt in Surah As-Syam, verses 7-8. which means: "... And the soul and refinement (His creation) then God inspires the soul the way of wickedness and piety. Surely it is fortunate that people purify their souls and actually lose those who pollute them.

The first characteristic formation in Islamic education is the emphasis on the search for knowledge, mastery and development on the basis of worship to Allah SWT. As a worship, then in the search for knowledge, mastery and development of science are stressed on moral values. In this context, honesty, disagreement, respect for sources of knowledge and so on are the principles of knowledge seeking. The second characteristic is the recognition of a person's potential and ability to develop in a personality [25].

One of the problems faced by the world of education is the problem of the weak learning process. In the learning process, children are not encouraged to develop thinking skills. Children are directed to memorize information without being required to understand it and associate it with everyday life. So when they graduated, they were theoretically clever, but poor application. This is because children are not expected to have intelligence, ability to solve life problems and also not directed to form creative and innovative people [26]. 
The goals to be achieved by education are essentially an embodiment of the ideal values formed in the human person. The ideal values in question are Islamic. This implies that the purpose of Islamic education is to realize Islamic ideals. Islamic idealism essentially contains the value of human behavior which is based on or imbued by faith and piety to God as an absolute source of power that must be obeyed.

The process of achieving educational goals is always directed at the Qur'an Surah AlqAlaq verse 1-5, which was first revealed by Allah to the Prophet is Iqra. Which means: Read in the name of your Lord Who created. He has created man from a blood clot. Read it, and your Lord is the Most Gracious, Who teaches (man) by means of kalam. He taught humans what he did not know. Reading using reason facilities means trying to develop intellectuality. And at the same time developing the soul in reading, researching, understanding and paying attention to all the abilities of mind and heart, so that the mind and soul will be more submissive and calm [27].

\section{Conclusion}

Humans with all their functions in the world, can develop as much as possible. Through the potential of the mind, the heart and the passions of mankind can achieve the right way of life in the world and achieve a better degree of life. Human potential is very relevant to the world of education and the process of achieving educational goals which are always directed at the Qur'an Surah al-Alaq verse 1-5, which Allah first sent to the Prophet. Through research, hope the results can be effective for humans in order to achieve happiness in the world and the hereafter.

\section{Acknowledgement}

This research can be done because of the support of all parties, especially my campus, Universitas Muhammadiyah Yogyakarta. Thank you, head of department, dean, and also the team of writers who took the time and energy so that this paper was written.

\section{References}

[1] A. David and M. B. Hantla, "An Intelligence Critique of Multiple Intelligence, a Christian Review for Leaders," J. Biblic. Perspect. Leadersh., vol. 4, no. 1, pp. 3-16, 2012.

[2] B. Gokhan, "Integrating Multiple Intelligence in ESL/EFL Classrooms," Internet TESL J., vol. XIV, no. 5, pp. 1-6, 2008.

[3] J. Hanafin, "Multiple Intelligence Theory, Action Research and Teacher Professional," Aust. J. Teach. Educ., vol. 39, 2014.

[4] A. Rachman, "Mengembangkan Kecerdasan Emosi Dan Spiritual," Psikoislamika, vol. 2, no. 2, 2005.

[5] M. Kamil, Membuka Hati Membuka Jendela Langit: Zikir untuk Identifikasi dan Aktualisasi Potensi Diri. Solo: C-Harde, 2004.

[6] K. Sholeh, Kecerdasan Majemuk Berorientasi pada Partisipasi Peserta Didik. Yogyakarta: Pustaka Pelajar, 2016.

[7] Sugiyono, Cara Mudah Menyusun Skripsi, Tesis dan Disertasi. Bandung: Alfabeta, 2015.

[8] R. A. Arthur S. Reber, Emily Reber, The Penguin Dictionary Of Psychology Terjemahan. Yogyakarta: Pustaka Pelajar, 2010.

[9] M. Q. Shihab, Metode Pendekatan Tafsir dalam Keilmuan Islam. Tangerang: Lentera Hati, 2008.

[10] Koentjaraningrat, Metode Penelitian Masyarakat. Jakarta: Gramedia, 1983.

[11] S. Arikunto, Prosedur Penelitian Suatu Pendekatan Praktek. Jakarta: Rineka Cipta, 2006. 
[12] A. A. Yusuf, Islam dan Sains Modern Sentuhan Islam Terhadap Berbagai Disiplin Ilmu. Bandung: Pustaka Setia, 2006.

[13] S. Khasinah, "Hakikat Manusia Menurut Pandangan Islam dan Barat," J. Ilm. Didakt., vol. XIII, no. 2, pp. 296-317, 2013.

[14] K. Sihotang, Filsafat Manusia Upaya Membangkitkan Humanisme. Yogyakarta: Tiara Wacana, 2003.

[15] M. D. Rahardjo, Ensiklopedia Al-Qurân Tasfir Sosial Berdasarkan Konsep-konsep Kunci. Jakarta: Paramadina, 2002.

[16] Hamka, Tafsir Al Azhar: Juz I-9, Diperkaya dengan Pendekatan Sejarah, Sosiologi, Tasawuf, Ilmu Kalam, Sastra dan Psikologi. Jakarta: Gema Insani, 2015.

[17] M. A.-S. Hasbi, Tafsir Al-Qurânul Majĩd An-Nûr. Semarang: PT. Pustaka Rizki Putra, 2016.

[18] A. Sutoyo, Manusia dalam Perspektif Al-Qurân. Yogyakarta: Pustaka Pelajar, 2015.

[19] A. M. Al-Maraqi, Tafsir al-Maragi, terj. Anshari Umar Sitanggal. Semarang: Toha Putra, 1992.

[20] M. A. Al-Shabuni, Tafsir al-Maragi, terj. Anshari Umar Sitanggal. Beirut: Dar al-Kutub alIslamiyyah, 1999.

[21] S. Quthb, Tafsir fi Dzilalil Quran. Jakarta: Gema Insani, 2016.

[22] I. Nugroho, Kepemimpinan Perpaduan Iman, Ilmu dan Akhlak. Yogyakarta: Pustaka Pelajar, 2016.

[23] Hamka, Kesepaduan Iman dan Amal Sakeh. Jakarta: Gema Insani, 2016.

[24] M. Arifin, Filsafat Pendidikan Islam. Jakarta: Bumi Aksara, 2009.

[25] A. Azra, Pendidikan Islam Tradisi dan Modernisasi Menuju Milenium Baru. Jakarta: Logos, 1999.

[26] W. Sanjaya, Strategi Pembelajaran Berorientasi Standar Proses pendidikan. Jakarta: Prenada Media Group, 2014.

[27] W. Sayadi, Hadis Tarbawi : Pesan-pesan Nabi SAW tentang Pendidikan. Jakarta: Pustaka Firdaus, 2011. 